\title{
COMPARISON OF SINGLE- AND DOUBLE-PLATE FIXATION TECHNIQUES IN THE TREATMENT OF NONUNIONS OF THE HUMERAL SHAFT
}

\author{
COMPARAÇÃO DE TÉCNICAS DE FIXAÇÃO DE \\ PLACA SIMPLES E DUPLA NO TRATAMENTO DE \\ PSEUDOARTROSE DO CORPO DO ÚMERO
}

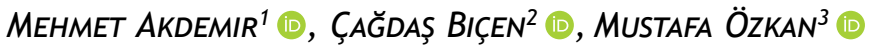 \\ 1. Izmir Ekol Hospital, Department of Orthopedics and Traumatology, Izmir, Turkey. \\ 2. Izmir University of Economics Medical Park Hospital, Department of Orthopedics and Traumatology, Izmir, Turkey. \\ 3. Dokuz Eylül University Hospital, Department of Orthopedics and Traumatology, Izmir, Turkey.
}

\section{ABSTRACT}

Introduction: Humerus shaft fractures may be treated conservatively or surgically. In $2.5 \%$ to $13 \%$ of cases, nonunion is observed, and it leads to severe pain and morbidity. Plate osteosynthesis has become popular in the treatment of nonunion of the humeral shaft. In this study, we compared the clinical outcomes of patients with humerus shaft nonunion whom we treated with single- or double-plate fixation. Materials and Methods: Fifty-three patients diagnosed with aseptic humeral shaft nonunion and treated with plate fixation were included in the study. Patients were evaluated according to the number of plates (single vs. double plates). The two groups were subjected to statistical evaluation according to their clinical and radiographical results. Results: The average age of the patients was 53 years (range: 1-86); 28 (52.8\%) were female and 25 (47.2\%) were male. The union rate was $90.32 \%$ for single plate and $90.91 \%$ for double plate fixation. There was no statistically significant difference between single and double plates in the clinical and radiographical results (union time, union rate, $Q$-DASH score) $(p>0.05)$. There was a significant correlation between age and union times / Q-DASH scores according to the Spearman correlation test $(p<0.05)$. Transient radial nerve neuropraxia developed in 2 patients and 1 patient suffered from an infection that was treated with debridement and antibiotic therapy. Conclusion: In our study, similar good results were obtained with single and double plates. In treatment of humeral shaft nonunions, a second plate is not needed if enough stability is provided with single plate fixation. Level of evidence III, Retrospective comparative study.

Keywords: Humerus. Fracture. Diaphysis.

\section{RESUMO}

Introdução: As fraturas do corpo do úmero podem ser tratadas de modo conservador ou cirúrgico. Em 2,5\% a 13\% dos casos, observa-se pseudoartrose, que causa dor intensa e morbidade. A osteossíntese com placas tornou-se popular para tratamento da não união da diáfise do úmero. Neste estudo, comparamos os resultados clínicos de pacientes com pseudoartrose do corpo do úmero que tratamos com fixação de placa simples ou dupla. Materiais e Métodos: Cinquenta e três pacientes com diagnóstico de pseudoartrose asséptica do corpo do úmero tratados com placa de fixação foram incluídos no estudo. Os pacientes foram avaliados de acordo com o número de placas (placa simples vs. dupla). Os dois grupos foram submetidos à avaliação estatística de acordo com seus resultados clínicos e radiográficos. Resultados: A média de idade dos pacientes foi de 53 anos (variação: 1 a 86); 28 (52,8\%) eram do sexo feminino e 25 (47,2\%) do sexo masculino. A taxa de união foi de 90,32\% para placa simples e 90,91\% para placa dupla. Não houve diferença estatisticamente significante entre a osteossíntese com placas simples ou duplas nos resultados clínicos e radiográficos (tempo de união, taxa de consolidação e escores do Q-DASH) $(p>0,05)$. Houve correlação significativa entre idade e tempo de união/escores do Q-DASH, de acordo com o teste de correlação de Spearman ( $p<$ 0,05 ). A neuropraxia transitória do nervo radial desenvolveu-se em dois pacientes e um paciente teve infecção tratada com desbridamento e antibioticoterapia. Conclusões: Em nosso estudo, resultados igualmente bons foram obtidos tanto com placas simples quanto duplas. No tratamento de pseudoartroses do corpo do úmero, uma segunda placa não é necessária se houver estabilidade suficiente com a fixação com placa única. Nível de evidência III, Estudo comparativo retrospectivo.

Descritores: Úmero. Fratura. Diáfise.

Citation: Akdemir M, Biçen Ç, Özkan M. Comparison of single- and double-plate fixation techniques in the treatment of nonunions of the humeral shaft. Acta Ortop Bras. [online]. 2022;30(1): Page 1 of 4. Available from URL: http://www.scielo.br/aob.

All authors declare no potential conflict of interest related to this article.

The study was conducted at Dokuz Eylül University Hospital, Department of Orthopedics and Traumatology, Izmir, Turkey.

Correspondence: Çağdaş Biçen. Izmir University of Economics Medical Park Hospital, Department of Orthopedics and Traumatology, Imbatlı, 1825 Sk., 35575 Karşıyaka/Izmir/Turkey. cagdasbicen@hotmail.com 


\section{INTRODUCTION}

Humeral shaft fractures constitute $3-5 \%$ of all fractures and conservative treatment results are generally good. ${ }^{1,2,3}$ The nonunion rate after humeral fracture ranges from $2.5 \%$ to $13 \% .{ }^{4,5}$ When nonunion is not treated, daily life is severely restricted due to pain and the patient's inability to use the affected limb. Nonunion must be treated surgically in cases of humeral shaft fractures. ${ }^{6,7}$

Several methods have been described in the treatment of humeral shaft fracture nonunion such as plate fixation, intramedullary nailing or external fixation. ${ }^{8,9}$ Today, plate fixation is more commonly preferred in the treatment of aseptic nonunion. 9,10 Grafting and fixation are recommended with a narrow dynamic compression plate with at least seven screws with 4.0-4.5 mm diameter. ${ }^{11,12}$ However, fixation with double plates can be performed in patients who are elderly, have osteoporosis, have undergone multiple surgeries, or have fractures in the proximal or distal shaft that cannot be fixed with a total of seven screws. ${ }^{13,14}$

In this study, we compared demographic data of the patients with humeral shaft nonunion who were treated surgically in our hospital. We also wanted to evaluate the union rates and clinical scores of shoulders of patients treated for humeral shaft nonunion with single or double plates. The aim of this study, was to evaluate the need for an additional plate and advantages or disadvantages of a second plate for humerus shaft nonunions.

\section{Patients and methods}

The humerus diaphyseal region was defined as the area between the pectoralis major attachment point and the epicondylar line. Patients who did not achieve union within six months with conservative or surgical methods and who were followed for at least one year after surgery were included in the study. Pathological fractures, infected cases of nonunion, type $3 \mathrm{~b}$ or $3 \mathrm{c}$ open fractures, patients whose skeletal maturity was not yet complete, and patients with intraarticular extension fractures were excluded from the study. Clinical evaluation of the patients was performed according to the Quick DASH (Disabilities of Arm, Shoulder, and Hand) (Q-DASH) score. Bone union was evaluated radiologically with bone callus formation and bone bridges in at least three cortices and clinically regression of pain in the fracture site.

Patients treated with plates with the diagnosis of humeral shaft nonunion were identified from the hospital records. This examination identified 57 patients who had plate osteosynthesis due to nonunion of humeral shaft fractures. Four patients were excluded from the study because their radiological and clinical records were incomplete. Thus, 53 patients were included in the study.

All of the patients were operated on in our clinic by three orthopedic surgeons. The surgeries were performed with a single plate for 31 patients and with double plates for 22 patients.

The fracture site of the patients was proximal in 9 cases, middle in 30 cases, and the distal shaft in 14 cases. Seven patients had hypertrophic and 46 patients had atrophic nonunion. Nonunion developed in 14 patients after conservative treatment, in 34 patients who had one surgery (plate in 18 cases, intramedullary nailing in 12 cases and external fixator in 4 cases), and in five patients who had multiple surgeries. The average time from the fracture to the last surgery was 19.49 months (range: 6-108).

For single-plate fixation, narrow plates and screws with $4.5 \mathrm{~mm}$ diameter were used. Plates were applied through a lateral incision to the anterolateral aspect of the bone. (Figure 1) In double-plate fixation, plates of $3.5 \mathrm{~mm}$ were applied to the anterolateral and lateral sides with a lateral incision. (Figure 2) An iliac crest autograft was applied in both groups. The radial nerve was exposed in all patients and interposed in the soft tissue at the end of the surgery. (Figure 3) Patients used a long arm splint for two weeks postoperatively, and
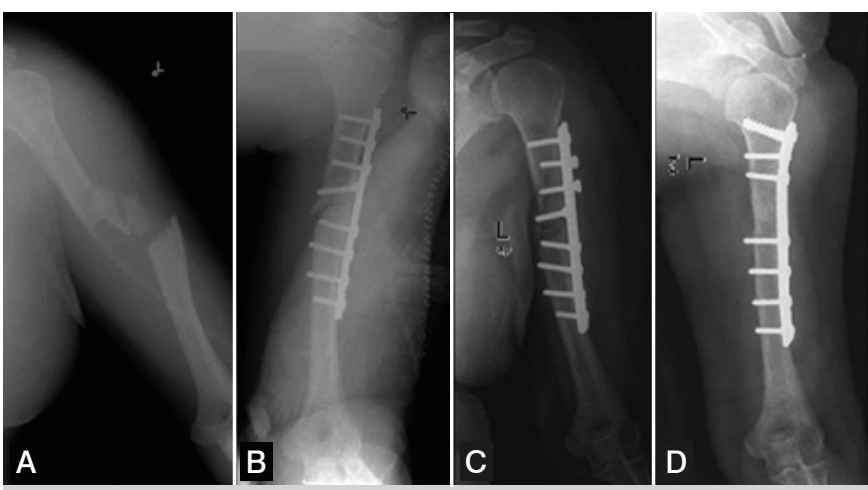

Figure 1. A) $X$ ray of a 50 year old female patient with left humerus fracture due to falling. B) Open reduction and fixation with $4.5 \mathrm{~mm}$ DCP plate. C) Nonunion on the ninth month. D) Grafting and fixation with a single plate in treatment of nonunion.
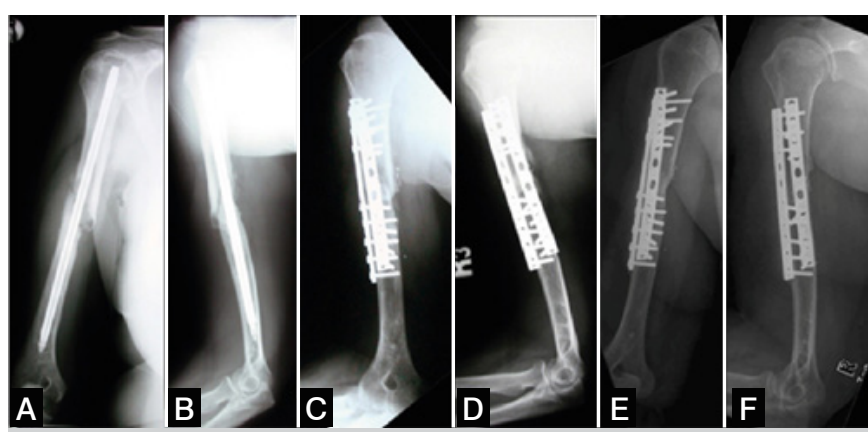

Figure 2. A) AP humerus view showing nonunion of a 54-year-old female patient, whose humerus diaphysial fracture was treated with intramedullary fixation B) Lateral humerus view showing nonunion C) AP humerus view of the patient on early postoperative period nonunion treated by fixation with double plates. D) Lateral humerus view of the patient on early postoperative period E) AP humerus view showing union on postoperative sixth month. F) Lateral humerus view showing union on postoperative sixth month.

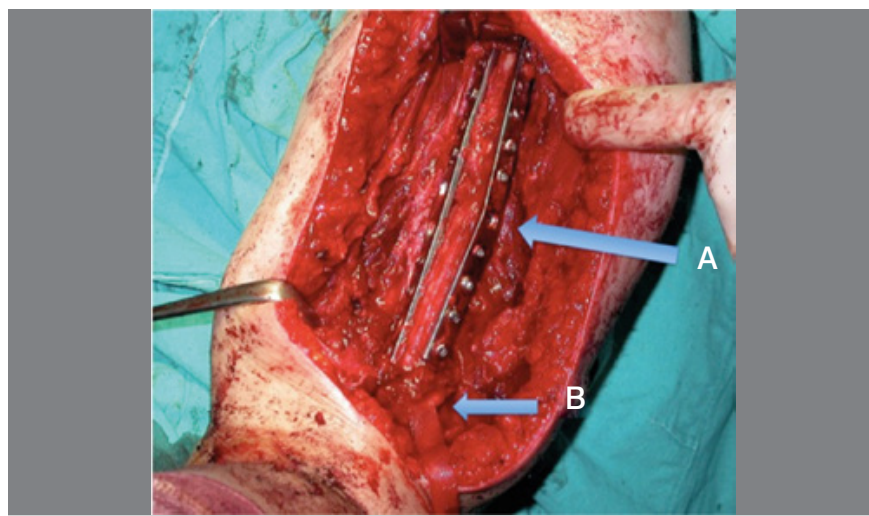

Figure 3. A) Intraoperative image of the patient treated with grafting and fixation with double plates. Second plate was bended in order to compress the graft. B) The radial nerve was exposed and protected.

after the stitches were removed and soft tissue edema decreased, the splint was removed and physical therapy was started.

For statistical evaluation, the data were uploaded to Microsoft Excel, and SPSS 17 was used for data analysis. The patients were divided into groups as those treated with a single plate or double plates. The Shapiro-Wilk normality test was applied to decide which tests should be used to compare the numerical data between these groups. According to normality test results, numerical data (age, Q-DASH score, union time, interval from fracture occurrence to time 
of last surgery, follow-up time) were compared between the two groups employing nonparametric Mann-Whitney "U" test. Cross tables were created for analysis of categorical data (gender, side, presence of union, nonunion type). For the analysis of categorical data Pearson's chi-square test was used. When the expected frequency was less than five in at least one cell of the cross table, Fisher's exact test was applied. Correlations between age, Q-DASH scores, and union times were checked by Spearman's correlation test. For all tests, $p<0.05$ was accepted as statistically significant.

\section{RESULTS}

The mean age of all patients was 53.09 (range: 21-86) years, and $52.8 \%(n=28)$ of the patients were female while $47.2 \%(n=25)$ were male. In $45.3 \%(n=24)$ of the patients, nonunion was present in the right humerus and in $54.7 \%(n=24)$ nonunion had occurred in the left.

When patients treated with single plates and double plates were compared, there was no statistically significant difference between the mean ages of the two groups according to the Mann-Whitney $U$ test $(p=0.162, p>0.05)$. There was no significant difference between gender and side distribution between the two groups according to Pearson's chi-square test $(p=0.442$ and $p=0.561$, $p>0.05$ ). (Table 1)

There was no statistically significant difference in types of nonunion (atrophic vs. hypertrophic) between the two groups according to Fisher's exact test $(p=0.431, p>0.05)$. The intervals from fracture occurrence to time of last surgery were compared with the Mann-Whitney $U$ test and no statistically significant difference was found $(p=0.136, p>0.05)$. (Table 1 )

The patients were followed for an average of 39.24 months (range: 12-133). The mean Q-DASH score of the patients was 19.45 (range: $0-81.18)$. In 5 patients we could not achieve union (9.43\%). Thus, the union rate was $90.57 \%$. Union was achieved in an average of 5.10 (range: 3-12) months. Comparisons of follow-up times, Q-DASH scores, and union time averages between groups were performed by Mann-Whitney $U$ test. In statistical evaluation, no significant difference was found between the groups ( $p=0.130$, $p=0.792$, and $p=0.525$ ). The difference between the union rates of the two groups was evaluated with Fisher's exact test and no statistically significant difference was found ( $p=0.662, p>0.05)$. (Tables 1 and 2)

A statistically significant correlation was found between the Q-DASH scores and union times according to age of the patients by Spearman's correlation analysis ( $p=0.037, p=0.000, p<0.05$ ).

Table 1. Comparison of general demographics of the patients.

\begin{tabular}{|c|c|c|c|c|c|c|}
\hline & & \multicolumn{2}{|c|}{ Single plate } & \multicolumn{2}{|c|}{ Double plate } & $p$ value \\
\hline \multicolumn{2}{|c|}{ Age (years) } & \multicolumn{2}{|c|}{$50.52+/-17.27$} & \multicolumn{2}{|c|}{$56.73+/-15.85$} & $0.162^{*}$ \\
\hline \multirow{2}{*}{ Gender } & Male & 16 & $\% 51.61$ & 9 & $\% 40.91$ & \multirow{2}{*}{$0.442^{\star *}$} \\
\hline & Female & 15 & $\% 48.39$ & 13 & $\% 59.09$ & \\
\hline \multirow{2}{*}{ Side } & Right & 13 & $\% 41.94$ & 11 & $\% 50.00$ & \multirow{2}{*}{$0.561^{\star *}$} \\
\hline & Left & 18 & $\% 58.06$ & 11 & $\% 50.00$ & \\
\hline \multirow{3}{*}{ Region } & Proximal & 6 & $\% 19.35$ & 3 & $\% 13.64$ & \multirow{3}{*}{$0.131^{* *}$} \\
\hline & Middle & 20 & $\% 64.52$ & 10 & $\% 45.45$ & \\
\hline & Distal & 5 & $\% 16.13$ & 9 & $\% 40.91$ & \\
\hline \multirow{2}{*}{$\begin{array}{l}\text { Nonunion } \\
\text { type }\end{array}$} & Atrophic & 28 & $\% 90.32$ & 18 & $\% 81.82$ & \multirow{2}{*}{$0.431^{\star \star \star}$} \\
\hline & Hypertrophic & 3 & $\% 9.68$ & 4 & $\% 18.18$ & \\
\hline \multicolumn{2}{|c|}{ Follow up time (months) } & \multicolumn{2}{|c|}{$41.05+/-20.02$} & \multicolumn{2}{|c|}{$37.97+/-31.94$} & $0.130^{*}$ \\
\hline \multicolumn{2}{|c|}{$\begin{array}{l}\text { Duration of nonunion } \\
\text { (months) }\end{array}$} & \multicolumn{2}{|c|}{$23.23+/-24.73$} & \multicolumn{2}{|c|}{$16.84+/-17.04$} & $0.136^{*}$ \\
\hline
\end{tabular}

*:Mann-Whitney U test. ${ }^{* *}$ : Pearson's chi-square test. ${ }^{* * *}$ : Fisher's exact test
Table 2. Comparison of clinical and radiological results of the patients.

\begin{tabular}{|c|c|c|c|c|}
\hline & & & & $p$ value \\
\hline \multirow{2}{*}{ Q-DASH score } & S.P. & \multicolumn{2}{|c|}{$16.91+/-16.43$} & \multirow{2}{*}{$0.792^{*}$} \\
\hline & D.P. & 20.68 & 25.03 & \\
\hline \multirow{2}{*}{ Union time (months) } & S.P. & 4.96 & 2.027 & \multirow{2}{*}{$0.525^{\star}$} \\
\hline & D.P. & 5.25 & 2.049 & \\
\hline \multirow{2}{*}{ Union status } & S.P. & $\% 90.32(+)$ & $\% 9.68(-)$ & \multirow{2}{*}{$0.662^{\star *}$} \\
\hline & D.P. & $\% 90.91(+)$ & $\% 9.09(-)$ & \\
\hline
\end{tabular}

[S.P. (single plate), D.P. (double plate)]. *: Mann-Whitney U test. **: Fisher's exact test.

Postoperative radial nerve neuropraxia developed in two patients with single plates and one patient with double plates. At the end of the 6th month, spontaneous regression was seen in all three patients. In a patient treated with a single plate, infective drainage occurred in the postoperative first month. Culturing was performed and methicillin-resistant Staphylococcus aureus was isolated. The infection regressed after debridement and antibiotic treatment. Healing occurred in this patient without the need for plate removal.

\section{DISCUSSION}

In the treatment of nonunion of humeral shaft fractures, intramedullary nails, plate fixation, and external fixation options are available..$^{8,9}$ Intramedullary fixation is not recommended in the treatment of complex nonunion of the humeral shaft. ${ }^{15}$ External fixation is mostly preferred in cases of infected nonunion due to the difficulty of patient compliance. ${ }^{16,17}$

Today, the refreshing of fracture ends, plate fixation, and bone grafting have become gold standards in the treatment of nonunion of the humeral shaft. ${ }^{9,18,19}$ Fixation with a plate and at least 7 screws with 4.0-4.5 mm diameter is advised, providing both biomechanically stable fixation and good compression.,11 The reason for this is that the most important cause of surgical failure in humeral shaft nonunion is inadequate fixation. ${ }^{11}$

In a biomechanical study, the humerus was fixed in four different ways: 1) a single plate, 2) a single plate and an additional interfragmentary screw, 3) double plates, and 4) double plates and an additional interfragmentary screw. The most stable fixation was found in the 4 th group. ${ }^{13}$ However, it was observed that there was no stability difference between the 1st and 3rd groups. This biomechanical study showed that a well-made single plate can be as stable as double plates. In another biomechanical study, it was emphasized that a single plate cannot provide good stability in patients with a short humerus and a second plate may be needed in such cases. ${ }^{20}$

In the literature, regarding the treatment of humeral shaft nonunion, there are few studies comparing the results of patients with single and double plates. Double-plate fixation was first performed by Murray et al. in 1964. ${ }^{21}$ In a study in which the results of union with double plates were evaluated, $100 \%$ union and an average union time of 4.6 months were obtained. ${ }^{22}$ In their clinical and biomechanical study, Rubel et al. did not detect any differences between single-plate fixation and double-plate fixation. They achieved union in an average of 4.8 months in $92 \%$ of their patients. ${ }^{13}$ Similarly, in our study, the union rate was $90.32 \%$ and the average union time was 4.96 months in patients treated with single plate and the rate of union was $90.91 \%$ and the union time was 5.25 months in patients treated with double plates.

In their case series, Feng et al. treated 3 of 6 long-term humerus nonunion patients with double plates and the other 3 with single plates and they achieved good clinical results. ${ }^{23}$ The authors suggested using a second plate if necessary in the treatment of long-term humeral shaft nonunion. In our study, the interval from fracture to the final surgery of the patients treated with double 
plates was 23.23 months on average, and this interval was 16.84 months among that patients with single plates. Although there was no statistically significant difference between the two groups $(p=0.136, p>0.05)$, patients treated with double plates had on average a longer nonunion time.

Age is also an important factor in long-bone nonunion treatment. ${ }^{24}$ The complication rate is expected to be high in these patients due to both bone quality deterioration and concomitant diseases. ${ }^{25}$ Therefore, applying two plates may provide better stabilization in cases of nonunion in the elderly or osteoporotic patients.,13,26 In a biomechanical study, one plate with 8 holes was applied to the lateral aspect of the humerus and one plate with a different number of screws was applied to the anterior one. The authors suggested a combination of 8-4 screws in young patients and 8-8 in elderly osteoporotic patients. ${ }^{14}$ In two clinical studies focusing on elderly and osteoporotic humeral shaft nonunion, the union rates of the patients were found to be over $90 \%$. ${ }^{5,27}$ Nonunion treatments were mostly performed with a single plate, but special plates (blade plates, wave plates) and double plates were also applied. In both studies, it was stated that the results were good when more stable fixation was obtained in osteoporotic and elderly patients. There are also studies suggesting strengthening the bone and increasing stability. ${ }^{7,28,29}$ Those researchers aimed at increasing the stability of the bone quality by extramedullary or intramedullary strut grafts and were generally successful.

The limitations of our study are its retrospective design and the relatively small number of patients. Prospective randomized studies on the treatment of humeral nonunion should be conducted with higher numbers of patients. On the other hand, at the literature most of the studies on humeral shaft nonunions are case series. In our study two different methods of plate fixation is compared statistically.

\section{CONCLUSION}

The importance of stabilization has been understood in the treatment of humeral shaft nonunion. When good stabilization is achieved with a single plate, it gives clinical results that are as good as those ones of double plates. Presence of additional plate doesn't have a significant effect on clinical and radiological outcomes. In cases in which stabilization cannot be achieved with a single plate, such as in osteoporotic and elderly patients, in patients with fractures close to the proximal or distal shaft ends, or in patients with a short humerus, additional stabilization with a second plate may be an alternative. Disadvantage of a second plate can be thought as; extended approach and extra cost of the plate. We think that additional plate is not needed in treatment of humeral shaft nonunions.

AUTHORS' CONTRIBUTION: Each author contributed individually and significantly to the development of this article. Akdemir M: writing, intellectual concept of the article and performing surgeries; Biçen Ç: designing and review of the article and data analysis; Özkan M: data analysis and performing surgeries.

\section{REFERENCES}

1. Peters RM, Claessen FM, Doornberg JN, Kolovich GP, Diercks RL, van den Bekerom MP. Union rate after operative treatment of humeral shaft nonunion--A systematic review. Injury. 2015;46(12):2314-24

2. Tsai $\mathrm{CH}$, Fong YC, Chen YH, Hsu CJ, Chang $\mathrm{CH}$, Hsu HC. The epidemiology of traumatic humeral shaft fractures in Taiwan. Int Orthop. 2009;33(2):463-67.

3. Perez EA. Canale ST, Beaty JH (eds). Fractures of the shoulder, arm, and forearm. 11th edn. Mosby Elsevier, Philadelphia, 2008.(3) 3371-460

4. Healy WL, White GM, Mick CA, Brooker AF, Weiland AJ. Nonunion of the humeral shaft. Clin Orthop. 1987; 219:206-13.

5. Ring D, Perey BH, Jupiter JB. The functional out- come of operative treatment of ununited fractures of the humeral diaphysis in older patients. J Bone Joint Surg (Am). 1999;81: 177-90.

6. Borus TA, Yian EH, Karunakar MA. A case series and review of salvage surgery for refractory humeral shaft nonunion following two or more prior surgical procedures. lowa Orthop J. 2005;25:194-9.

7. Hornicek FJ, Zych GA, Hutson JJ, Malinin TI. Salvage of humeral nonunions with onlay bone plate allograft augmentation. Clin Orthop Relat Res. 2001;(386):203-9.

8. Atalar AC, Kocaoglu M, Demirhan M, Bilsel K, Eralp L. Comparison of three different treatment modalities in the management of humeral shaft nonunions (plates, unilateral, and circular external fixators). J Orthop Trauma. 2008;22(4):248-57.

9. Padhye KP, Kulkarni VS, Kulkarni GS, et al. Plating, nailing, external fixation, and fibular strut grafting for non-union of humeral shaft fractures. J Orthop Surg. 2013;21(3):327-31.

10. Lin CL, Fang CK, Chiu FY, Chen CM, Chen TH. Revision with dynamic compression plate and cancellous bone graft for aseptic nonunion after surgical treatment of humeral shaft fracture. J Trauma. 2009;67(6):1393-6.

11. Marti RK, Verheyen CC, Besselaar PP. Humeral shaft nonunion: evaluation of uniform surgical repair in fifty-one patients. J Orthop Trauma. 2002;16(2):108-15.

12. Volgas DA, Stannard JP, Alonso JE. Nonunions of the humerus. Clin Orthop Relat Res. 2004;(419):46-50.

13. Rubel IF, Kloen P, Campbell D, Schwartz M, Liew A, Myers E, et al. Open reduction and internal fixation of humeral nonunions: a biomechanical and clinical study. J Bone Joint Surg Am. 2002;84(8):1315-22.

14. Karakasli A, Basci O, Ertem F, Sekik E, Havitcioglu H. Dual plating for fixation of humeral shaft fractures: A mechanical comparison of various combinations of plate lengths. Acta Orthop Traumatol Turc. 2016;50(4):432-6.

15. Ilyas I, Younge DA. Locked intramedullary nailing for difficult nonunions of the humeral diaphysis. Int Orthop. 2003;27(5):278-81.

16. Lammens J, Bauduin G, Driesen R, et al. Treatment of nonunion of the humerus using the Ilizarov external fixator. Clin Orthop Relat Res. 1998;(353):223-30.
17. Patel VR, Menon DK, Pool RD, Simonis RB. Nonunion of the humerus after failure of surgical treatment. Management using the llizarov circular fixator. $J$ Bone Joint Surg Br. 2000;82(7):977-83.

18. Hsu TL, Chiu FY, Chen CM, Chen TH. Treatment of nonunion of humeral shaft fracture with dynamic compression plate and cancellous bone graft. J Chin Med Assoc. 2005;68(2):73-6.

19. Bernard de Dompsure R, Peter R, Hoffmeyer P. Uninfected nonunion of the humeral diaphyses: review of 21 patients treated with shingling, compression plate, and autologous bone graft. Orthop Traumatol Surg Res. 2010;96(2):139-46.

20. Watts A, Weinhold P, Kesler W, Dahners L. A biomechanical comparison of short segment long bone fracture fixation techniques: single large fragment plate versus 2 small fragment plates. J Orthop Trauma 2012;26(9):528-32.

21. Murray WR, Lucas DB, Inman VT. Treatment of non-union of fractures of the long bones by two-plate method. J Bone Joint Surg Am. 1964;46:1027-048.

22. Martinez AA, Cuenca J, Herrera A. Two-plate fixation for humeral shaft non-unions. J Orthop Surg. 2009;17(2):135-8.

23. Feng D, Zhang J, Zhu Y, Wu S, Shan J, Ye A, et al. Plate fixation with autogenous bone grafting for longstanding humeral shaft nonunion: A retrospective study of 6 cases. Medicine (Baltimore). 2018;97(35):e11974.

24. Zura R, Braid-Forbes MJ, Jeray K, Mehta S, Einhorn TA, Watson JT,et al. Bone fracture nonunion rate decreases with increasing age: A prospective inception cohort study. Bone. 2017;95:26-32.

25. Ekegren CL, Edwards ER, de Steiger R, Gabbe BJ. Incidence, Costs and Predictors of Non-Union, Delayed Union and Mal-Union Following Long Bone Fracture. Int J Environ Res Public Health. 2018;15(12):2845.

26. Ring D, Jupiter JB, Quintero J, Sanders RA, Marti RK. Atrophic ununited diaphyseal fractures of the humerus with a bony defect: treatment by wave-plate osteosynthesis. J Bone Joint Surg Br. 2000;82(6):867-71.

27. Ring D, Kloen $P$, Kadzielski J, Helfet D, Jupiter JB. Locking compression plates for osteoporotic nonunions of the diaphyseal humerus. Clin Orthop Relat Res. 2004;(425):50-4

28. Van Houwelingen AP, McKee MD. Treatment of osteopenic humeral shaft nonunion with compression plating, humeral cortical allograft struts, and bone grafting. J Orthop Trauma. 2005;19(1):36-42.

29. Vidyadhara S, Vamsi K, Rao SK, Gnanadoss JJ, Pandian S. Use of intramedullary fibular strut graft: a novel adjunct to plating in the treatment of osteoporotic humeral shaft nonunion. Int Orthop. 2009;33(4):1009-14. 